\section{Several pharmaceuticals impaired harbor seal lymphocytes (Phoca vitulina) in vitro}

\author{
C. Kleinert, ${ }^{1}$ M. Mournier, ${ }^{1,2}$ \\ M. Fortier,' P. Brousseau, ${ }^{1}$ \\ S. DeGuise, ${ }^{3}$ M. Fournier
}

'Institut National de la Recherche

Scientifique (INRS)-Institut Armand-

Frappier, Laval, Canada; ' ${ }^{\text {UFR des }}$

Sciences Pharmaceutiques et Biologiques,

Université de Montpellier, France;

${ }^{3}$ Department of Pathology, University

of Connecticut, Storrs, CT, USA

\section{Introduction}

In human and veterinary therapeutics, approximately 3000 different drugs are used and prescribed in high quantities. ${ }^{1}$ The main substance classes are steroidal hormones, antimicrobials and pharmaceuticals and their metabolites. ${ }^{1,2}$ These compounds could become problematic in the environment, because $>80 \%$ of the drugs pass the body without being biotransformed, and furthermore their elimination in sewage treatment plants is incomplete. ${ }^{1,3}$ Additionally, the compounds are constructed for a specific intended effect on living beings, and therefore show intrinsic physico-chemical behavior. ${ }^{4}$ Since the compounds are chemically different and peer-reviewed ecotoxicological data is available for less than $1 \%$ of human pharmaceuticals, the effects on most trophic levels of aquatic life are hard to predict for a single substance or a mix of various ones. ${ }^{5-8}$ The purpose of this study was to identify the impact of pharmaceuticals commonly found in surface waters on immune cells of harbor seals (Phoca vitulina) in vitro. Peripheral blood mononuclear cells (PBMCs) from captive seals and a seal B lymphoma cell line (11B7501) ${ }^{9}$ were exposed to selected single substances. Compounds of interest were analgesics (ibuprofen, naproxen), psychoactive substances (carbamazepine, paroxetine), antibiotics (erythromycin, sulfamethoxazole, trimethoprim), cholesterol lowering compounds (gemfibrozil), steroidal hormones (ethynyl estradiol) and caffeine.

\section{Materials and Methods}

\section{Sampling and isolation of peripher- al blood mononuclear cells and cell culture}

Whole blood samples (7-15 mL) were collect- ed from the extradural intervertebral vein of four female harbor seal adults in captivity (Aquarium du Québec, Quebec, Canada). Blood was kept in heparin tubes at RT for $6 \mathrm{~h}$ after sampling until separation with Lympholyte-Mammal (Cedarlane, Burlington, Canada). The PBMCs were resuspended in completed RPMI-1640 and kept at $4^{\circ} \mathrm{C}$ overnight until the start of the incubation with xenobiotics.

The 11B7501 cell line ${ }^{9}$ was maintained at concentrations between $2.0 \times 10^{5}-2.0 \times 10^{7}$ cells/mL in completed RPMI-1640 in a humidified $5 \% \mathrm{CO}_{2}$ atmosphere.

\section{Preparation of xenobiotics}

Chemicals (all Sigma-Aldrich) were dissolved in dimethyl sulfoxide (DMSO), ethanol or water. The final concentration of DMSO or ethanol in the samples never exceeded $0.1 \%$.

\section{In vitro exposures}

For the in vitro exposures, cells were adjusted to the test specific concentration. In case of the lymphoblastic proliferation $200 \mu \mathrm{L}$ of cells (1.25 $\times 10^{6}$ cells $\left./ \mathrm{mL}\right)$ were incubated with $2 \mu \mathrm{L}$ of pharmaceutical product. In case of phagocytosis and cell cycle and apoptosis, $500 \mu \mathrm{L}$ of cells $\left(1.0 \times 10^{6}\right.$ cells $/ \mathrm{mL}$ and $0.5 \times 10^{6}$ cells $/ \mathrm{mL}$, respectively) were incubated with $5 \mu \mathrm{L}$ of pharmaceutical product. Viability assays were set up parallel to each of the three assays as an additional control.

For the experiments with PBMCs, concentrations of pharmaceuticals were based on environmentally relevant values found in municipal effluents. The concentration $1 x$ refers to the maximum concentration detected in the environment (Table 1), as cited. ${ }^{10,11}$ Further concentrations tested were: $0 \mathrm{x}, 0.01 \mathrm{x}$, $0.1 \mathrm{x}, 10 \mathrm{x}, 100 \mathrm{x}$ (Table 1).

In experiments with the 11B7501 cell line, concentrations of pharmaceuticals were increased to be able to observe a possible negative impact of the single substance on the harbor seal immune cells (Table 1).

\section{Viability assay}

After the respective exposure time, viability of cells was evaluated using $4 \mu \mathrm{L}$ of a $100 \mu \mathrm{g} / \mathrm{mL}$ of propidium iodide (PI) solution (SigmaAldrich) to $500 \mu \mathrm{L}$ of cell suspension. A FACSCalibur (Becton Dickinson, San Jose, CA, USA) with an air-cooled argon laser providing an excitation at $488 \mathrm{~nm}$ was used. For each sample 5000 events were acquired at a fluorescence emission of $620 \mathrm{~nm}$ (FL3). The cell population was electronically gated in a FSC/SSC dot plot and the fluorescence frequency distribution histogram was obtained using FL3. The percentage of dead cells was determined using a marker. Data collection and analysis were performed with the
Correspondence: Christine Kleinert, Institut National de la Recherche Scientifique (INRS)Institut Armand-Frappier, Laval, H7V 1B7, Canada. E-mail: Christine.Kleinert@iaf.inrs.ca

Key words: immune system, Phoca vitulina, pharmaceuticals.

Conference presentation: part of this paper was presented at the ECOBIM meeting, 2013 May, Montréal, Quebec, Canada.

Acknowledgements: the study was supported by the Canada Research Chair in Immunotoxicology (MF) and the NSERC Strategic Grant. CK was supported by a scholarship of the German Academic Exchange Service (DAAD). Furthermore, we would like to thank Stéphane Masson and his team at the Aquarium du Québec for providing us with whole blood samples.

This work is licensed under a Creative Commons Attribution NonCommercial 3.0 License (CC BYNC 3.0).

(C) Copyright C. Kleinert et al., 2013

Licensee PAGEPress, Italy

Journal of Xenobiotics 2013; 3(s1):e5

doi:10.4081/xeno.2013.s1.e5

CellQuest Pro software (Version 4.0.1). The results were expressed in percentage of viable cells.

\section{Phagocytosis assay}

Phagocytosis was measured using carboxylate coated fluorescent latex beads (Polysciences Inc.; 100 beads: 1 cell). After $24 \mathrm{~h}$ exposure to single substances of pharmaceuticals, cells and beads were incubated for $1.5 \mathrm{~h}$ at $37^{\circ} \mathrm{C}$ to allow attachment and phagocytosis. To remove most free beads after incubation, the suspension was centrifuged on a gradient of 3\% BSA (MP Biomedicals) prepared in completed medium. The fluorescence emission was collected at $520 \mathrm{~nm}$ (FL1). For each sample 10,000 events were acquired. Using a FSC/SSC dot plot, the adequate population was electronically gated and the fluorescence frequency distribution histogram was obtained using FL1. Data was expressed as percentage of cells with phagocytic activity (cells that engulfed $>$ one bead) and phagocytotic efficiency (cells that engulfed>three beads). The lymphocyte population was gated as a negative control.

\section{Lymphocyte transformation assay}

Change in DNA synthesis after stimulation with a mitogen [Con A for PBMCs, lipopolysaccharide (LPS) for 11B7501 cell line] was measured as the incorporation of methyl- ${ }^{3} \mathrm{H}$-thymidine. After $48 \mathrm{~h}$ incubation, $1 \mu \mathrm{Ci}$ of methyl- ${ }^{-3} \mathrm{H}$ thymidine (PerkinElmer, Shelton, USA) was 
added and cells were incubated for further $18 \mathrm{~h}$. The cells were harvested onto a glass fiber filter (Tomtec Mach III Cell Harvester) and the amount of radioactivity incorporated was measured with a TriLux counter (Wallac 1450 MicroBeta TriLux Liquid Scintillation Counter \& Luminometer) and analyzed with the program MicroBeta Windows Workstation (Version 4.50.09, PerkinElmer, Shelton, USA). The raw data was expressed as counts per minute and was then converted in percent proliferation of control.

\section{Cell cycle and apoptosis assay}

The DNA content of each cell was measured using PI. After fixation of the cells with $70 \%$ EtOH following the $24 \mathrm{~h}$ exposure and $72 \mathrm{~h}$ in RPMI, cells were washed and then resuspended in a PBS solution containing PI $(50 \mu \mathrm{g} / \mathrm{mL})$ and RNAse (100 $\mu \mathrm{g} / \mathrm{mL})$ (all Sigma-Aldrich). PI also binds to double stranded regions of RNA, necessitating treatment with nucleases. ${ }^{12}$ Using the FSC/SSC dot plot, the cell population was electronically gated and the fluorescence frequency distribution histogram using FL2 $(585 \mathrm{~nm})$ was obtained. In a second dot plot, the gated lymphocyte population is expressed in FL2-A/FL2-W. Doublets (two $G_{1} / G_{0}$ cells attached to each other, which seem to have the same DNA content as one cell in the $G_{2} / M$ phase) are discriminated using a second gate. The population lymphocytes minus doublets was analyzed in FL3-A, and apoptosis as well as the phases of the cell cycle were gated independently. For each sample 5000 events were acquired. The results were expressed in percentage of cells in different stages of the cell cycle plus apoptotic events.

\section{Statistical analyses}

Differences between controls and treated groups were evaluated by one-way ANOVA followed by Tukey's Multiple Comparison post test. The calculations were performed using GraphPad Prism 5 for Windows (GraphPad Software). The level of significance was set at $\mathrm{P} \leq 0.05$.

\section{Results and Discussion}

The experiments conducted with PBMCs exposed to concentrations of pharmaceuticals similar to those found in surface showed no significant impairment of cellular function in the phagocytosis or lymphoblastic proliferation assay (data not shown).

In the experiments with the 11B7501 cell line, three compounds influenced the B lymphocytes at high concentrations. While the phagocytosis experiment showed no significant effect with any compound (data not shown), the lymphoblastic proliferation with LPS was modulated in the case of naproxen $\left(>25 \mu \mathrm{g} / \mathrm{mL}^{* *}\right)$ and carbamazepine ( $\left.>50 \mu \mathrm{g} / \mathrm{mL}^{*}\right)$ (Figure 1A). The cell cycle and apoptosis assay revealed a significant increase in apoptotic events at $50 \mu \mathrm{g} / \mathrm{mL}$ for ethynylestradiol, while the percentage of cells in the $\mathrm{G} 2 / \mathrm{M}$ phase decreased (Figure 1B). For carbamazepine, the percentage of apoptotic events slightly decreased at $50 \mu \mathrm{g} / \mathrm{mL}$, while the percentage of cells in the G0/G1 phase increased (Figure 1B).

The absence of an effect in the lower doses of pharmaceutical compounds does not neces-

Table 1. Concentration range of pharmaceutical compounds tested with PBMCs and the 11B7501 cell line. For the experiments with PBMCs, test concentrations of single substances were chosen according to values found in municipal effluents. The maximum value found in literature was set to be the $1 x$ concentration. Further concentrations tested were $0 \mathrm{x}, 0.01 \mathrm{x}, 0.1 \mathrm{x}, 10 \mathrm{x}$ and $100 \mathrm{x}$ of the $1 \mathrm{x}$ value. Concentration ranges of the single substances for the experiments with the $11 \mathrm{~B} 7501$ cell line were then increased.

\begin{tabular}{|c|c|}
\hline Compound & PBMCs \\
\hline
\end{tabular}

\begin{tabular}{|c|c|c|c|}
\hline Caffeine & 800 & Verlicchi et al., $2010^{11}$ & $0.125-25$ \\
\hline Ibuprofen & 300 & Verlicchi et al., 2010 ${ }^{11}$ & $0.125-25$ \\
\hline Gemfibrozil & 30 & Verlicchi et al., 2010"11 & $0.25-50$ \\
\hline Naproxen & 20 & Verlicchi et al., $2010^{11}$ & $0.25-50$ \\
\hline Sulfamethoxazole & 12 & Terzic et al., $2008^{10}$ & $0.25-50$ \\
\hline Trimethoprim & 6 & Verlicchi et al., $2010^{11}$ & $0.25-50$ \\
\hline Carbamazepine & 2 & Verlicchi et al., 2010"11 & $0.25-50$ \\
\hline Erythromycin & 0.4 & Terzic et al., $2008^{10}$ & $0.25-50$ \\
\hline Ethynylestradiol & - & - & $0.25-50$ \\
\hline Paroxetine & - & - & $0.25-50$ \\
\hline
\end{tabular}

PBMCs, peripheral blood mononuclear cells.

A) Lymphoblastic proliferation with lipopolysaccharide
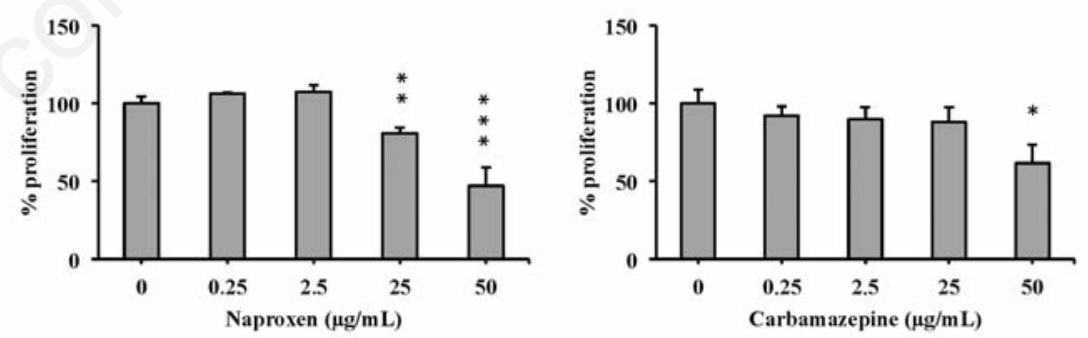

B) Cell cycle and apoptosis
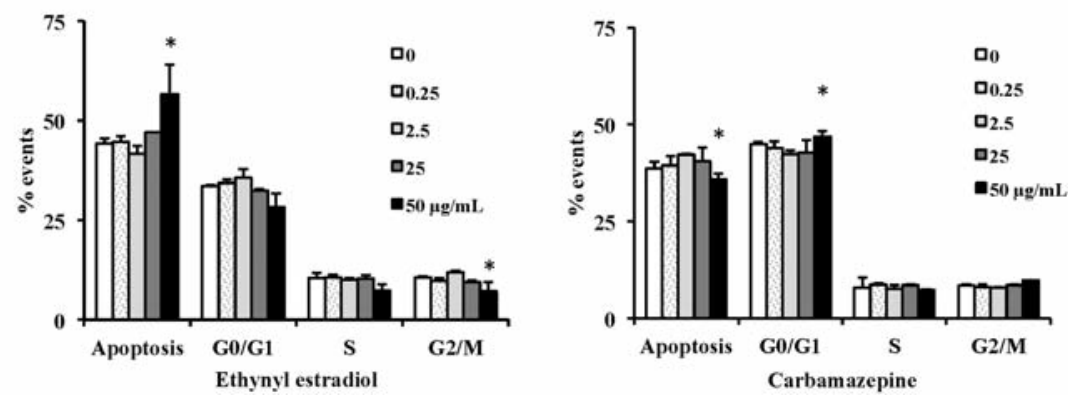

Figure 1. The lymphoblastic proliferation assay revealed significant effects for naproxen and carbamazepine (A). The cell cycle and apoptosis assay showed significant effects for ethynyl estradiol and carbamazepine (B). Significant differences are expressed by an asterisk $\left({ }^{*} \mathbf{P}<\mathbf{0 . 0 5},{ }^{* *} \mathbf{P}<\mathbf{0 . 0 1},{ }^{* *} \mathbf{P}<\mathbf{0 . 0 0 1}\right)$. 
sarily conclude to the harmlessness of current environmentally relevant levels of pharmaceuticals towards the immune system of marine vertebrates. In contrast, many studies on fish already showed bioaccumulation in various tissues and a significant change in immune parameters, behavior and distribution that were caused by environmentally relevant levels of pharmaceuticals. ${ }^{13-16}$ With fish accumulating pharmaceutical products and seals being piscivorous, they will likely be exposed to higher concentrations through nutrition, opposed to those concentrations found in the water column. Therefore, the true environmentally relevant concentrations for the exposures of marine mammals towards pharmaceuticals still have to be assessed.

Our study shows that more sensitive methods are needed to evaluate the impact of pharmaceuticals on the immune system of marine mammals. Risk assessment in this area is necessary, because not only seals but also humans consume fish. If pharmaceuticals in the environment cause a possible reduction in certain functional activities of the immune system of large vertebrates that may alter the host's resistance to pathogens, the knowledge of these effects would therefore most certainly have implications on the treatment of municipal wastewaters in the future.

\section{References}

1. Togola A, Budzinski H. Analytical development for analysis of pharmaceuticals in water samples by SPE and GC-MS. Anal Bioanal Chem 2007;388:627-35.

2. Gagné F, Blaise C, Fournier M, Hansen PD. Effects of selected pharmaceutical prod- ucts on phagocytic activity in Elliptio complanata mussels. Comp Biochem Phys C 2006;143:179-86.

3. Halling-Sørensen B, Nors Nielsen S, Lanzky PF, Ingerslev F, Holten Lützhøft HC, Jørgensen SE. Occurrence, fate and effects of pharmaceutical substances in the environment - A review. Chemosphere 1998; 36:357-94.

4. Sanderson H, Johnson DJ, Reitsma T, Brain RA, Wilson CJ, Solomon KR. Ranking and prioritization of environmental risks of pharmaceuticals in surface waters. Regul Toxicol Pharm 2004;39:15883.

5. Jones OAH, Voulvoulis N, Lester JN. Aquatic environmental assessment of the top 25 English prescription pharmaceuticals. Water Res 2002;36:5013-22.

6. Sanderson H, Johnson DJ, Wilson CJ, Brain RA, Solomon KR. Probabilistic hazard assessment of environmentally occurring pharmaceuticals toxicity to fish, daphnids and algae by ECOSAR screening. Toxicol Lett 2003;144:383-95.

7. Stuer-Lauridsen F, Birkved M, Hansen LP, Lutzhoft HCH, Halling-Sorensen B. Erratum to "Environmental risk assessment of human pharmaceuticals in Denmark after normal therapeutic use" [Chemosphere 40 (2000) 783-793]. Chemosphere 2000;41:1509.

8. European Commission. White paper. Strategy for a future chemicals policy, COM (2001) 88 Final. Available from: http://ec.europa.eu/enterprise/sectors/che micals/documents/reach/archives/whitepaper/index_en.htm Accessed: 12 Nov 2012.

9. Frouin H, Fortier M, Fournier M. Toxic effects of various pollutants in 11B7501 lymphoma B cell line from harbour seal (Phoca vitulina). Toxicology 2010;270:6676.

10. Terzic S, Senta I, Ahel M, Gros M, Petrovi M, Barcelo D, et al. Occurrence and fate of emerging wastewater contaminants in Western Balkan Region. Sci Total Environ 2008;399:66-77.

11. Verlicchi P, Galletti A, Petrovic M, Barcelo D. Hospital effluents as a source of emerging pollutants: An overview of micropollutants and sustainable treatment options. J Hydrol 2010;389:416-28.

12. Suzuki T, Fujikura K, Higashiyama T, Takata K. DNA staining for fluorescence and laser confocal microscopy. J Histochem Cytochem 1997;45:49-53.

13. Hoeger B, Hitzfeld B, Kollner B, Dietrich DR, van den Heuvel MR. Sex and low-level sampling stress modify the impacts of sewage effluent on the rainbow trout (Oncorhynchus mykiss) immune system. Aquat Toxicol 2005;73:79-90.

14. Salo HM, Hébert N, Dautremepuits C, Cejka P, Cyr DG, Fournier M. Effects of Montreal municipal sewage effluents on immune responses of juvenile female rainbow trout (Oncorhynchus mykiss). Aquat Toxicol 2007;84:406-14.

15. Azzurro E, Matiddi M, Fanelli E, Guidetti P, La Mesa G, Scarpato A, et al. Sewage pollution impact on Mediterranean rocky-reef fish assemblages. Mar Environ Res 2010; 69:390-7.

16. Daughton CG, Brooks BW. Chapter 8: Active pharmaceutical ingredients and aquatic organisms. In: Beyer WN, Meador JP, eds. Environmental contaminants in biota: interpreting tissue concentrations. Boca Raton, FL: CRC Press, Taylor and Francis; 2011. pp 286-347. 